\title{
Web とDBMS連携によるデータベースシステムの開発
}

\author{
山本嘉一郎*
}

\section{Development of Databases by Connecting Web and DBMS}

\author{
Kaichiro Yamamoto ${ }^{*}$ \\ キーワード:データベース, インターネット, ホームページ, Web, DBMS
}

\section{1. まえがき}

コンピュータネットワークの普及にともない, データ ベースサービスの手段として Webが使用されることが多 くなっている. 利用者側は Web ブラウザソフトさえあれ ば，簡単にデータベースを利用することができる．従来の 専用インターフェースによるデータベース利用に比べて, 格段にその利便性は高い. さらにWebによるデータベー スサービスでは, 提供情報をマルチメディア化することが 容易である. 一方, Webのホームページにとっても, そ の情報提供・共有といった目的から見て, データベース機 能をそこに持たせることは，その機能を飛躍的に向上さ せ, より有効なサービスを実現することができる. 大規模 な情報提供のサービスから個人情報の管理まで, 広く利用 できる有用な技術である.

このようなサービスシステムは, ホームページが作成で きれば, パソコン用のデータベースソフトを利用する程度 の知識で構築することができる. ホームページの作成も, 最近ではほとんど, GUIベースの優れた開発ツールが提 供されており, ワープロ感覚で容易に作成することができ る.このように, ホームページ作成の中でも難しいとされ てきたデータの提供や収集といったデータベース連携のシ ステムが, 容易に構筑できるようになっている. 本講座で は, その仕組みとシステム開発の手順について解説する.

ホームページ上でデータベース検索などのサービスを行 うには, 当初, CGI (Common Gateway Interface) と呼ばれる仕組みを利用する必要があった。現在でも CGI は広く利用されており，開発できるシステムの自由 度も高い.ただ CGIを使ったシステムの開発は容易では なく，少なくともプログラムを自由に作成できる程度の技 能と知識が必要である．また，多様な機能のシステムを開 発できる利点はあるが, 開発には手間之時間がかかり開発
効率はよくない. そこで，いくつかのノンプログラミング な開発ツールが提供されている. その中から本講座では, マイクロソフトの Web サーバソフトである IISが提供す る機能を紹介する.

IIS で提供するホームページからのテータベースアクセ ス機能は Internet Database Connector（IDC）と呼ば れるものである（他にASP も提供されている），連携さ せるテータベースソフトには, 同社が提供するパソコン用 テータベースソフト MS - Access を使用することができ る. IIS は Windows NT Server に標準で添付されてお り，MS-Access は広く普及したDBMSである．また Windows NT Workstation や Windows 95 では, IISに 代えて Pear Web Serverや Personal Web Server を利用 することもできる.このように，必要な環境はほとんよ゙の 研究室や企業で用意できるものと思われる.

\section{Web とデータベース連携の仕組み}

\section{1 一般的な仕組み}

この仕組みは, ホームページを閲覧する利用者が要求す る情報をデータベースから取り出して, ホームページ上に 表示するものである.その流れは第 1 図のように表され る. 利用者はまず, ブラウザ（ホームページ閲覧ソフト） でそのホームページにアクセスし, ホームページ上で検索 条件や入力データなど, データベースへの要求を入力す る.この要求はそのホームページを提供しているサーバへ 送られる. ホームページに送られた要求は, Webサーバ ソフトの機能によりデータベースソフトに送られ, 要求に 従った処理が行われる. 要求が検索であるときはさらに, 検索結果がデータベースサーバから Webサーバへ返され る. 受け取った検索結果は, あらかじめ用意されたテンプ レート上にはめ込まれて, 結果表示用のページ（HTML

1998 年 6 月 8 日受付, 1998 年 6 月 11 日受理

*光華女子短期大学 Koka Women's Junior College, 38 Kadonocho, Nishikyogoku, Ukyo, Kyoto City, 615 - 0882 , Japan. e - mail: yamamoto@koka.ac.jp 
ファイル）が作成され, 利用者のブラウザに送られて表示 される.

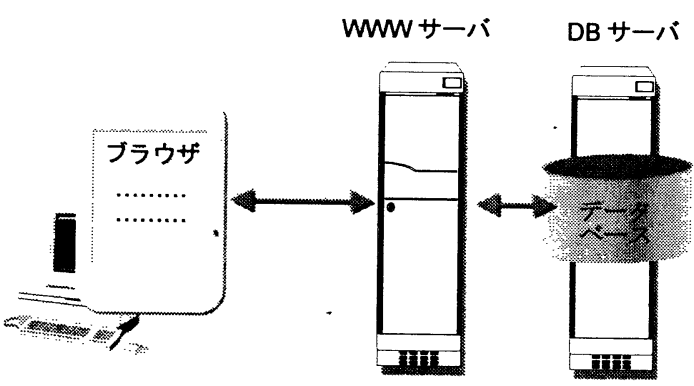

第 1 図Web とデータベース連携の一般的な仕組み

\subsection{IISにおける仕組み}

IIS における Web とデータベースの連携の仕組みは第 2 図（大澤文孝（1997）より）のよおりである. 利用者 による要求は Web ブラウザにより, Webサーバ（IISや Pear Web Serverなど）への要求情報の送信と IDC 形式 ファイルの呼び出しといった形で行われる. 利用者の画面 に表示されているページには, Webサーバ上のどの IDC 形式ファイルを呼び出すかといったことが記載されてお り，Webサーバは受け取った情報をこの IDC形式ファイ ルに渡す. 同時に図中の(2)にあるように, HTTPODBC というプログラムを起動する．IDC 形式ファイルには テータベースをどのように操作するかが記述されており, HTTPODBC はこの記述に従って, ODBC ドライバに SQL 文を発行する. ODBC ドライバは受け取った SQL 文を解釈してデータベースを操作する．ここで検索なよ゙， その結果が生じる操作であれば，データべースから ODBC ドラバはその結果を受け取り, HTTPODBCに返 す. HTTPDODBC はこれをあらかじめ用意された HTX

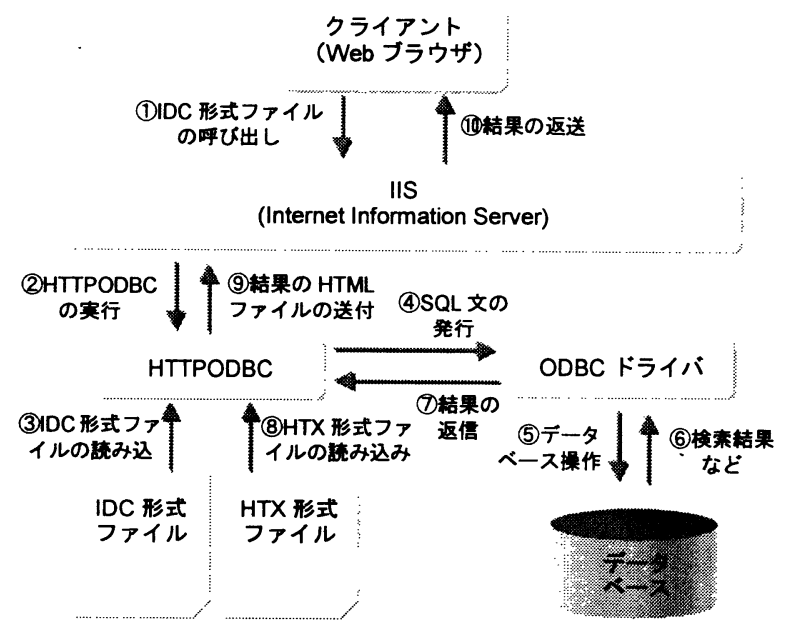

第 2 図 IISにおけるWeb とテータベース連携の仕組み
形式ファイルに埋め込んで，Web ブラウザ上で結果が表 示されるような HTML 形式のファイルを作成し，利用者 の Web ブラウザへ送って表示させる.

このように Web サーバとデーベースの連携処理は, HTTPDODBCが担当している．CGIではこれをシステ 厶開発者が作成する CGI アプリケーションで行ってお り, HTTPODBC は一種の汎用的な CGI アプリヶーショ ンと考えることができる．CGIではプログラミング言語 などを使って，処理の手順も含めて本格的なプログラムを 作成する必要があるが, HTTPODBCでは処理内容と処 理結果の表示様式を定める IDC および HTX ファイルを 用意するだけでよい.

\section{3. システムの開発とその手順}

\section{1 開発と運用に必要な㻴境}

IDC 機能を使ったデータベースサービスシステムの開 発には，次のような環境が必要である.

(1) Web サーバ

Windows NT Server/Workstation 4.0 または Windows 95 （おそらく98 も可）が動作しているパソコン又 はPCサーバ.

(2) Web サーバソフト

マイクロソフト IIS ( Internet Information Server ), Pear Web Server, あるいは Personal Web Server. 上記の OSにはこのいずれかが標準添付されている. (3)データベースサーバ

通常は, Web サーバと同一マシン上におけばよい. OS は Windows NT Server/Workstation 4.0 または Windows 95(おそらく98も可能)が必要である. DBMS には SQL サーバ，ORACLE，あるいはMS - Accessな ごが使用できる．ここでは特別な知識を必要とせず，パソ コンのパッケージソフトを利用する感覚で開発できる MS - Access を使用する. また, 32 ビットの ODBC ドライ バが必要である.これも上記の OSに標準で添付されてい る.

\section{2 開発に必要なこととその手順}

IDC 機能による Webをインタフェースとしたデータ ベースサービスシステムを開発するには, 次のような作業 が必要である. また，その一般的な手順はここに示すとお りである。

\section{データベースの用意}

ODBC の設定（データソースの用意）

ホームページ（フォーム）の作成

処理要求の入力様式の作成

IDC ファイルの作成

テータベース操作の指示

HTX ファイルの作成

処理結果の表示様式の作成 
4. MS - Access によるデータベースの準備

以下，1つの例をとりあげ，システム開発の具体的な手 順について解説する. 例としては, 第 1 表のような項目を もつ化石標本のデータベースを取り上げる．使用するデー タベースはデータベース JAFOV として開発・公開され ているものの一部である（山本他, 1997).

\begin{tabular}{l|l|l}
\hline \multicolumn{1}{c|}{ フィールド名 } & \multicolumn{1}{|c|}{ 内 容 } & データ型 \\
\hline RegistrationNo & 登録番号 & テキスト \\
\hline Name & 学名 & テキスト \\
\hline Portion & 部位 & テキスト \\
\hline Depository & 収蔵機関 & テキスト \\
\hline
\end{tabular}

第 1 表 例題として使用する化石標本のデータベース （項目リスト）

第 1 表のデータを MS - Access のデータベースとするに は, データベース (mdb) とテーブルの作成が必要であ る.ここでは，データベースファイル名を「 fossil. $\mathrm{mdb}$, テーブル名を「化石標本」とする.これを MS Access で定義するには, 第 3 図の奥のウィンドウのよう に, テータベースを「fossil.mdb」として作成した後, その中にテーブル「化石標本」の定義を行う．テーブルの 定義には第 3 図の手前のウィンドウのように, フィールド 名とその属性 (テータ型) が必要である. フィールドの説 明の入力は任意である．MS - Accessによるデータべー ス作成の詳細については，「Microsoft Access 97 ステップ バイステップ (アスキー出版局)」などを参照されたい.

\section{ODBC データベースの設定}

\subsection{ODBC の役割と基本}

ODBC (Open DataBase Connectivity ) ドライバ は, データベースを操作するアプリケーションとデータ ベース管理ソフトの間の仲介をするものである，ODBC ドライバを使用することにより, データベース管理ソフト

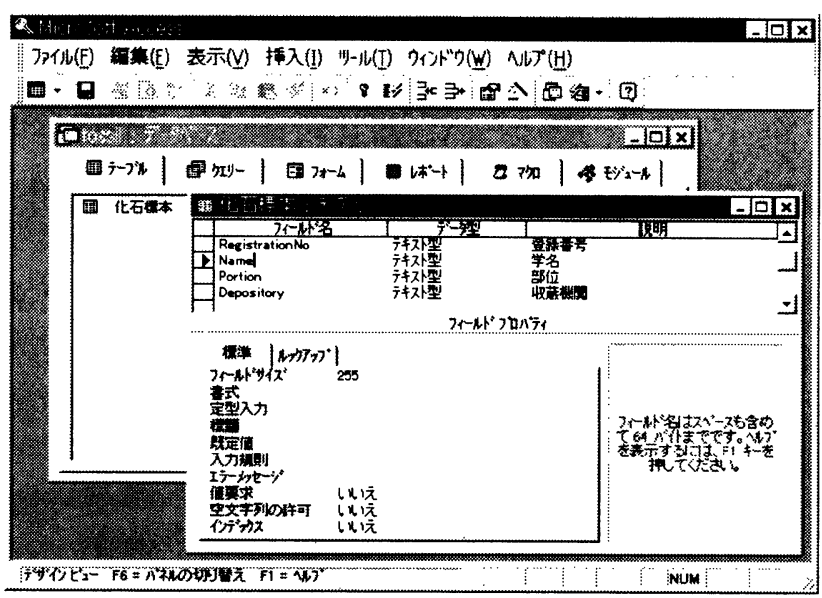

第 3 図 MS - Access におけるテータベースの準備
と独立にアプリケーションを開発することができる. ODBC は対象となるデータベースを管理するデータベー ス管理ソフト（DBMS）ごとに用意されており，ここで は MS - Access を対象データベースとする ODBC を使用 する.

ODBC を介して対象のデータベースを使用できるよう にするには，サーバ上でそのデータベースを，ODBC 対 象のデータベースとして登録する必要がある。この登録は データソースとしての定義という形で行う. データソース としての定義には, データソース名（Data Source Name ）を使用する. 適当なテータソース名を設けて, これに実際のデータベースファイルを割り当て, ODBC の種類（ODBC タイプ）を指定する. このようにするこ とにより, 対象のデータベースを扱うときに, よ゙の ODBC ドライバを使用すればよいかをアプリケーション に知らせられるようになっている. したがってアプリケー ション（この場合はIDC 形式ファイル）では，データ ベースを引用するときに，そのファイル名ではなくデータ ソース名を使用する.

\subsection{ODBCテータベースの設定手順}

MS - Access のデータベースを ODBC データベースと して扱えるようにするには, 次の手順により, Accessの データベースを ODBC システムデータソースとして割り 当てる.ここでは, データべースファイル fossil をデータ ソース名dsfossil で割り当ててみることにする.

(1) ODBC データソースアドミニストレータの起動

コントロールパネルの [ ODBC] をダブルクリックす ると, 第 4 図のような「ODBC データソースアドミニス トレータ」が起動する.

(2)システムデータソースの追加

第 4 図で,「システムDSN」タブを選択し，［追加］ ボタンを押す。これにより，第 5 図のような「データソー スの新規作成」ダイアログボックスが表示される.

(3)ドライバの選択

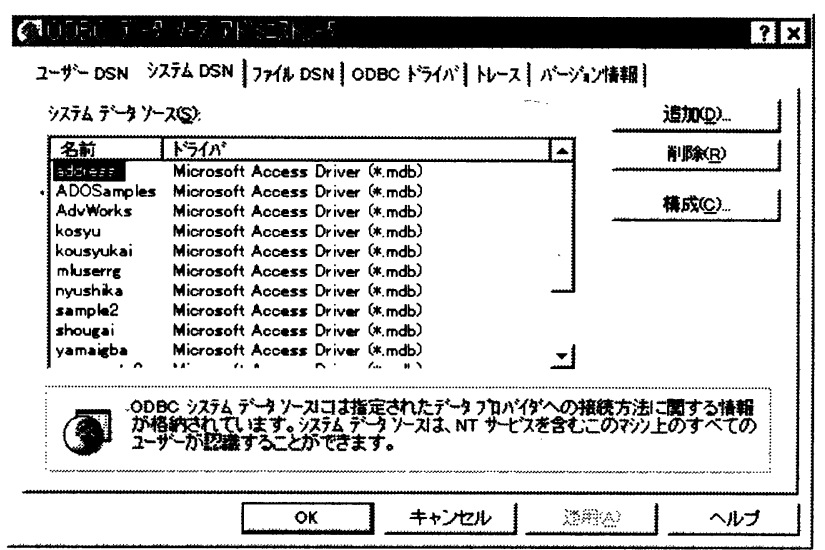

第 4 図 データソースの定義（その1） 
第 5 図上で, Microsoft Access Driver (*.mdb)を選 択して [完了] ボタンを押す.これにより，第 6 図のよう な ODBCのセットアップ用ダイアログボックスが表示さ れる.

(4)テータソース名の入力

第 6 図の「テータソース名」の右のテキストボックス に, データソース名を入力する. また必要ならば, その説 明をその下に入力することができる.

(5)データベースファイルの選択

このデータソース名に割り当てるデータベースファイル を選択する. 第 6 図の「データベース」セクションの中の

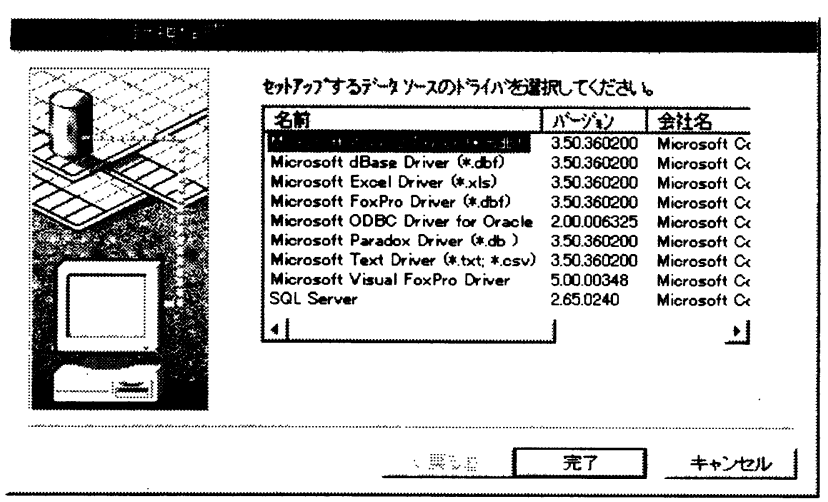

第 5 図 テータソースの定義（その 2）

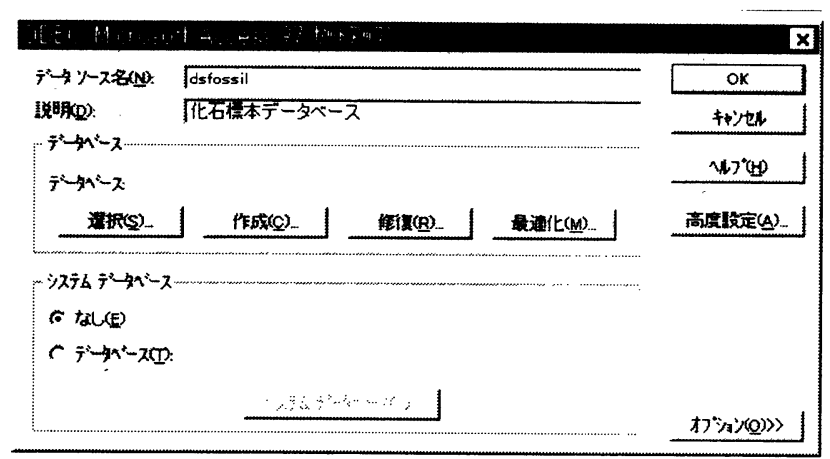

第 6 困 データソースの定義（その3）

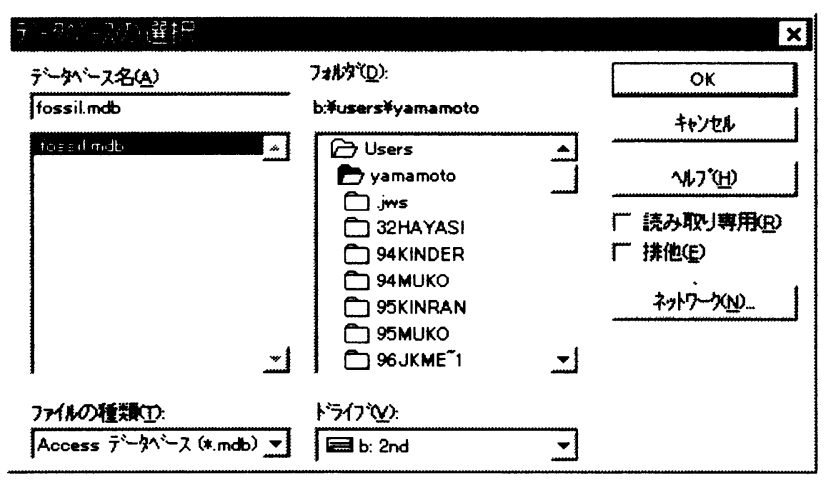

第 7 図 テータソースの定義（その4）
[選択］ボタンを押し，表示される第 7 図のようなダイア ログボックスで, 目的のデータベースファイルを選択して

[OK］ボタンを押す.

(6)手順を終了する

第 7 図, 第 5 図, 第 4 図之順次, それぞれのダイアログ ボックスで $[\mathrm{OK}]$ ボタンを押す.

\section{6. データ入カシステムの作成}

IDC 機能によるテータベース操作としては次のような ことが可能である.

$$
\begin{aligned}
& \text { テータの挿入 } \\
& \text { データの検索 } \\
& \text { テータの修正 } \\
& \text { テータの削除 }
\end{aligned}
$$

今回はこの中から, 比較的手順の簡単なテータの挿入之検 索を紹介することとし, まずテータの挿入機能を利用した データ入カシステムの作成法について解説する.

先にあげた「化石標本データベース」へデータを登録 (レコードを挿入) する場合を例に説明する．このシステ ムは第 8 図のページにテータを入力すると, 先に定義した

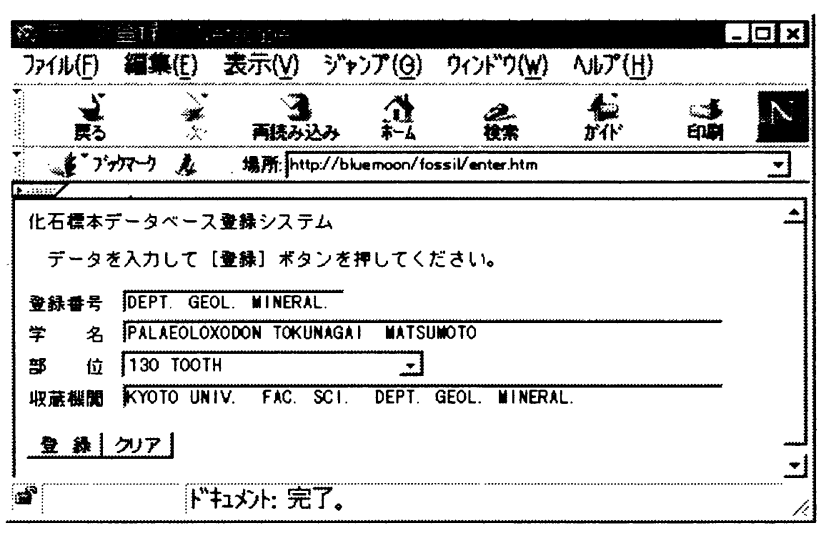

第 8 図 テータ登録のページ

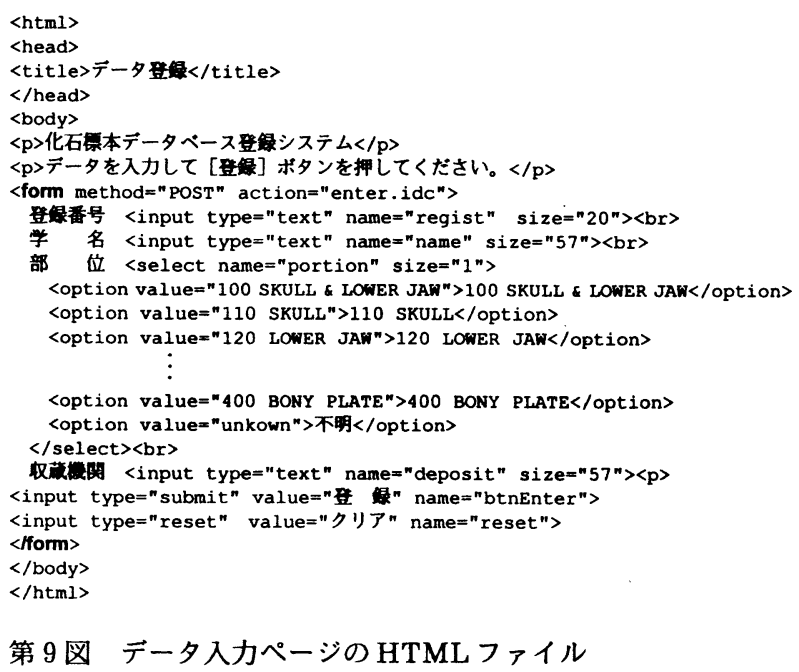


化石標本データベースに 1 つレレコードとして, データ が登録されるものである.

\section{1 処理要求のベージの作成}

この場合の処理要求を行うページの HTML ファイルは 第 9 図のようになる. < form>からく/form>の部分は フォームであり, 各テキストボックスにデータを入力して 「登録」ボタンを押すと，入力したデータが送られる. 同 時に, あらかじめ用意された IDC 形式のファイルが呼び 出される. [クリア] ボタンは入力值をクリアするボタン で，このボタンを押すと画面上の入力值がクリアされる （既にデータベースに送付したデータを取り消すものでは ない).

第 9 図はこのページの HTML ファイルである. 呼び出 されるべき IDC 形式のファイル（ファイル名は insert. idc）は, <form>タグの中に, 次のように記述されてい る.

action $={ }^{n}$ enter. idc ${ }^{n}$

その前に記入されている method パラメータについては 常に, $\operatorname{method}={ }^{\text {POST }}$ "とすればよい.

フォームを HTML で記述するには，〈form > ....</ form>タグを使用する. その中に<input>によるテキス トボックスや入力データの送信を行うためのコマンドボタ ン, <select $>\ldots</$ select $>$ によるドロップダウンメ ニュー（選択メニュー）を配置する.

テキストボックスの書式は次の例の通りで, <input> タグを使用し， typeパラメータを”text”とすればよい。

$<$ input type $=$ " text ${ }^{\prime}$ name $=$ " regist ${ }^{n}$ size $={ }^{n} 20 ">$ テキストボックスに入力された値を IDC ファイルに送る際

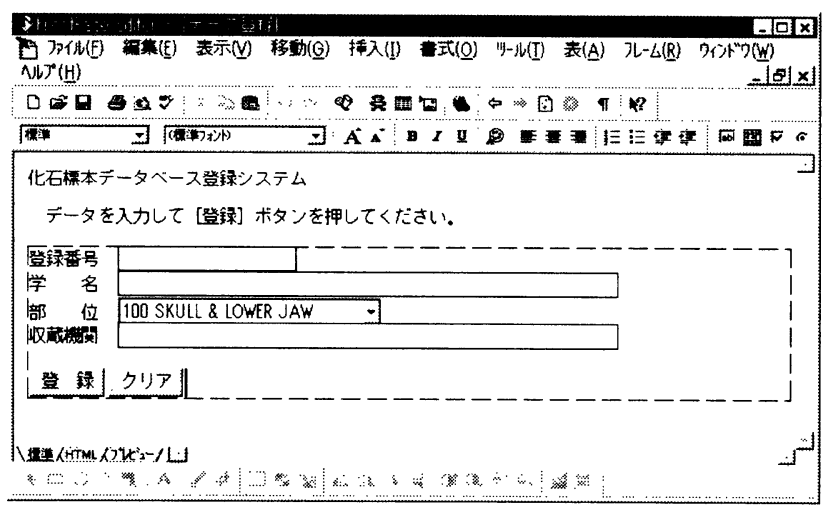

第 10 図 FrontPage Editorによるフォームの作成作業

Datasource: dsfossil

Template: enter.htx

SQLStatement:

+ INSERT INTO 化石標本 (RegistrationNo, Name, Portion, Depository)

+ VALUES ('zregistz', 'znamez', 'zportiong', 'zdepositz')

第11困 データ登録用 IDCファイル「enter.idc」
の変数名は, テキストボックス名として, name パラメー 夕に記述する，sizeパラメータは，そのテキストボック スへの入力を許可する文字数を指定するものである.

ドロップダウンメニューの書式は次の例の通りで，< select $>\ldots . . .</$ select $>$ タグを用いて, IDCファイルへ送 る際の変数名と選択肢を記述する.

$<$ select name $=$ "portion" $\operatorname{size}=" 1 ">$

<option value $=$ " 110 SKULL $">110$ SKULL </option> $<$ option value $=$ "120 LOWER JAW">120 LOWER JAW </option $>$

<option value $=$ " $400 \mathrm{BONY}$ PLATE"> $400 \mathrm{BONY}$ PLATE</option>

$</$ select $>$

nameパラメータはリストボックスの場合と同様で, この 值が IDC ファイルに送られたときに使用される変数名と なる，選択肢はこの例のように，valueパラメータととも に<option> ...</option>の間に記述する. ページ上には 後者が表示され, IDC ファイルにはvalue パラメータの 值が送られる。

HTML で直接これを書こうとするとやや煩雑で記述ミ スも起こり易いが，FrontPage Editorなよ゙のホーム ページ作成ソフトを使用すれば，第 10 図のような完成画 面のイメージにごく近い形で作成することができ，とくに HTML での記述の仕方を知らなくても容易に作成するこ とができる. FrontPage Editorについては, たとえば 「FrontPage98 ステップバイステップ（日経 BP ソフト プレス)」などを参照されたい.

\subsection{IDC ファイルの作成}

次に第 9 図のフォームからの処理要求を処理する IDC ファイルを作成してみよう. 第 11 図はそのための IDC ファイル（insert.idc）である.このように IDCファイ ルにはまず，次のような必須セクションの記述が必要であ る. 各セクションの記述例については，第 11 図を参照さ れたい.なお、IDCファイルを保存するフォルダは「実 行可能」にしておく必要がある.

Datasource セクション ODBC システムデータソース名を指定する.

Template セクション 処理結果を表示する際に使用する HTX 形式ファイル のファイル名を指定する.

SQLStatement セクション

データベースに対する処理内容を指示する SQL 文を 記述する.このセクションは複数，置くことができる. ここでは, データソース名はdsfossilなので, Datasource セクションには「Datasource: dsfossil」と記述 している. 使用するテンプレートのファイル（HTX 形式 
ファイル）の名前は「insert.htx」としているので, こ こには「Template: insert.htx」と記述している.

ここまではほとんど問題なく書けるであろう. 問題は SQLStatement セクションである.ここにはSQL文を書く が, SQL 文の主な機能は, レコードの挿入, 検索, 変更, 削除であり，それほど多くの命令があるわけではないので， 例文を見ながら当てはめればたいていのことはできる.

第11図の例では, フォームから送られたフィールド值 を1レコードとして, テーブル「化石標本」に挿入するも ので，SQL 文としては INSERT 文を使用する． INSERT 文の一般書式は次のとおりである.

INSERT INTO テーブル名（フィールド名の並び）

VALUE（フォーム上の変数の並び）

$\langle\mathrm{html}>$

$\langle$ head>

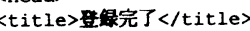

$</$ head $>$

<body>

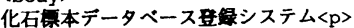

テータを1件、裂しましたくく〉

<a href="enter.htm">データ登録画面に戻る $</ a>$

$</$ body>

$</$ html $>$

第 12 図 テータ登録用の HTX ファイル「enter.htx」

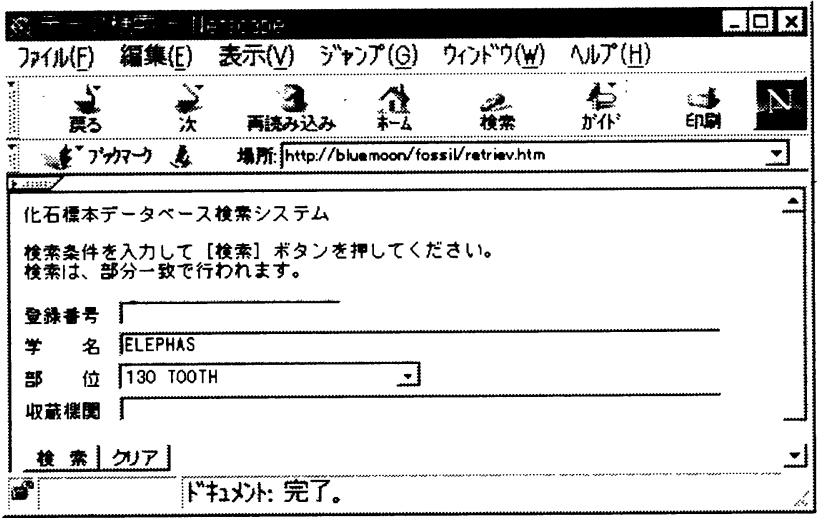

第13図 検索条件入力のページ

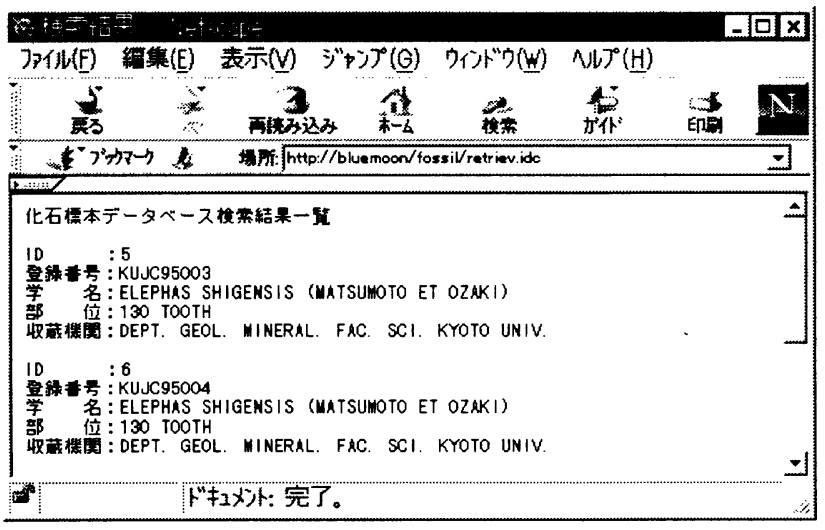

第14図 検索結果の表示例
ここでは，挿入する値が入っている変数（フォーム上で定 義）とデータベース上のフィールド名（Accessで定義） に対応付けて，第11図のように並べればよい。

\section{3ＨTX ファイルの作成}

レコードの挿入後は, 処理が終了したことを利用者のブ ラウザ画面上に表示することにする．HTX ファイルはそ の際， HTML ファイルを作成するために利用するテンプ レート (雛形) の役割を果たす. その処理（IDCファイル による処理）で得られた結果をこのテンプレートに埋め込 む形で出力表示用の HTML ファイルを作成する.

ここでは処理がレコードの挿入なので処理に伴う出力は ない. したがって,この場合の HTX ファイルは第 12 図 のように, 通常の HTML ファイルとなる.

\section{7. データ検索システムの作成}

化石標本のデータベースを検索するシステムを例に説明 する．このシステムは，第 13 図のページで検索条件を入 力して [検索] ボタンを押すと, その条件によるデータ ベースの検索が行われ，第 14 図のような形で検索結果が 表示されるものである.

\section{1 処理要求のベージの作成}

データベースに収録されている登録番号, 学名, 部位, 収蔵機関で検索することを考えてみる．検索方法は登録番 号と学名については部分一致とし, 部位と収蔵機関につい ては，検索值をぺージ上で選択できるようにする．

このページの HTML ファイルは第 15 図のようにな る.フォーム部分 (タグ<FORM $>$ から</FORM $>$ の部 分）には，検索条件の入力用テキストボックス，選択用リ ストボックス，IDC 起動用の [検索] ボタン，および入 力值をクリアする「クリア」ボタンを配置する.これらの 記述は入力用のファームの場合とほぼ同様である（6.1 節 参照).

$\langle h t m i>$

$<$ head $>$

$\langle$ title >データ検索</title>

$</$ head $>$

<body bgcolor $=$ "\#FFFFF" >

化石集本データベース梌索システムくp

娭索条件を入力して[検索] ボタンを押してください。くbr〉

娭索は、部分一致で行われます。<p>

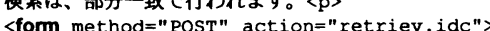

登錄番

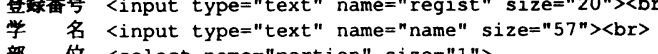

部位 <select name="portion" size="1">

<option> </option>

<option value $=" 100$ SKULL \& LOWER JAW">100 SKULL \& LOWER JAW</option> <option value $=" 110$ SKULL">110 SKULL</option>

<option value $=" 330$ LIMB" $>330$ LIMB $</$ option>

<option value $=" 400$ BONY PLATE" $>400$ BONY PLATE $</$ option $>$ $\langle/$ select $\rangle\langle$ br $>$

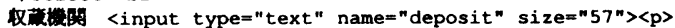

<input type="submit" value="模 " name="btnRTV">

〈input type $=$ "reset" value $=$ "クリア" name $=$ "reset">

$<$ iform $>$

$</$ body $>$

$</$ html $>$

第 15 図 テータ検索処理を要求するページの HTML ファイル 
IDC ファイルの呼び出しの部分は次のように, retriev.idcを呼び出すように記述する.

action $=$ "retriev.idc"

\subsection{IDC ファイルの作成}

この場合の IDC ファイルは第 16 図のようになる. Datasource セクションは入力の場合と同様, dsfossil で ある. Templateセクションは, 検索結果を表示すると きのテンプレートとして retriev.htx を用意するので, こ れを記述しておく.

SQLStatement セクションには, 処理要求フォームか ら送付された検索条件をもとに，「化石標本」テーブル上 で検索を行うための SQL 文を記述する．この場合の SQL 文は次のようになる.

\section{+ SELECT * FROM 化石標本}

+ WHERE RegistrationNo like '\%\%\%regist\%\%' and

+ Name like '\%\%\%name\%\%'

+ and Depository like '\%\%\%deposit\%\%' and Portion

+ like '\%\%\%portion\%\%'

SELECT 句, FROM 句，および WHERE 句から成 る. SELECT 句は検索後, どのフィールドを取り出すか を指定する．SELECT の後ろに取り出すフィールド名 （Access データベースでのフィールド名）を書く．ここ では全フィールドを取り出すことにしているので，「*」 を記入している. FROM句はどのテーブルから検索を行 うか, データソース内のテーブル名を指定する.

Datasource: dsfossil

+ SELECT * FROM 化石槙本

+ WHERE RegistrationNo like 'z8s regist 888 ' and Name like ' 88 z

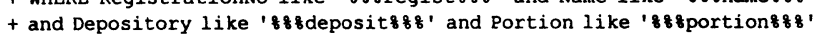

第16図 データ検索用 IDCファイル「retriev.idc」

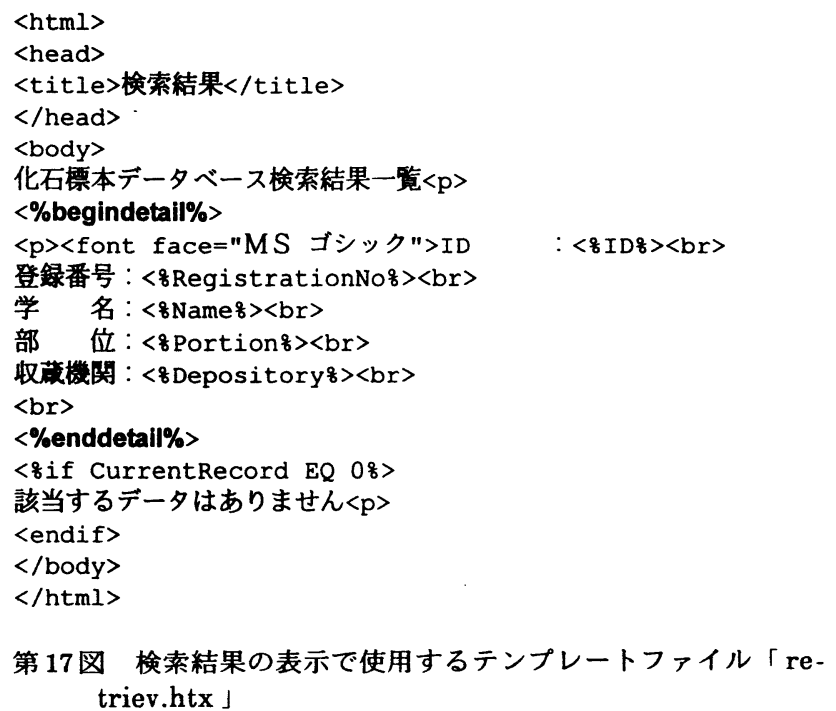

WHEER 句は検索条件を記述するもので. WHERE の後に記述された条件を満たすレコードが取り出される. ここでは4つのフィールドについて, 検索条件を指定して いる.たとえば, RegistrationNoフィールドについて は, 次のように指定している.

\section{RegistrationNo like '\%\% \%regist\%\%'}

これは,「RegistrationNoフィールドの值が，検索処理 要求のページから送られた変数 registの值を含む」とい う条件を意味する.このように部分一致の条件を与えると きはキーワード likeを使用する. 先にレコードの挿入の ところで述べたように, 処理要求のページからの変数を引 用するときは，その変数名の前後に\%を付ける.ここで\% がさらに2つずつ前後についているのは, いわゆるワイル ドカードの役割を果たすもので,「変数 registの值の前 後に何が入っていてもよい」という条件を意味する.

\subsection{HTX ファイルの作成}

第 16 図のIDCファイルが実行されると，その WHERE 句に記述された条件を満たすレコードが検索さ れ，そのフィールド值が HTX ファイル（ここでは retriev.htx ）に埋め込まれて, 検索結果を表示する HTML ファイルが作成される.これが利用者のブラウザに送られ て，第 14 図のように検索結果が表示される.

第 17 図はその HTX ファイルである. 当然ながら, そ の様式はHTML ファイルに似ており, 検索の結果として 得られるフィールド值をどこに埋め込むかを，「く\% フィールド名\%>」の形で記述する. さらに, 検索の結果 は通常, 複数レコードあることが想定されるので, 繰り返 し表示する範囲を指定する．この指定は，第 17 図中に太 字で示すように，〈\%begindetail\%〉とく\%enddetail\%>で 囲んで行う.このファイルの最後に置かれているくif CurrentRecord EQ 0\%>と<\%endif\%>は，検索結果が 0 レコードの場合に表示されるメッセージを定義するもので ある.

\section{8. あとがき}

今回の講座では, マイクロソフトが Web サーバのソフ トとともに提供するIDC と呼ばれる仕組みを使用して, Web とデータベースを連携させたシステムを開発する方 法について紹介した．Webとデータベースを連携させ て; 情報提供, データベース構築, あるいは情報管理のシ ステムを開発する方法には様々なものがあるが，ここで紹 介した方法は，比較的容易に，またどこにでもある環境で これを実現するものである，是非，試して見られたい。

今回は基本的な機能として, データの登録と検索の機能 の作成法を解説した. これだけでも十分, 実用的なものが 作成できるが, さらにデータの変更・削除といった機能を 必要とする場合もあろう。また, 登録の際に一度, 入力値 を確認したいということや, 検索時に, 詳細を見たいレ 
コードについてのみ全フィールド值を表示させたいといっ たこともあろう。これらの機能を実現する方法について も，機会を得て引き続き紹介していきたい.

\section{参考文献}

大澤文孝(1997)Web アプリケーション構築ガイド(IIS+ Accessによるデータ連携)。ソフトバンク株式会社,

359 p.

小川晃夫(1997) Access 97 ステップバイステップ. 株式 会社アスキー, 319p.

テクニカルコア(1998) FrontPage 98 ステップバイステッ プ. 日経 BPソフトプレス, 320p.

山本嘉一郎・西脇二一・河村善也(1997)在日本脊椎動物化 石標本データベース (JAFOV). 平成 8 年度文部省科学 研究助成費報告書, $26 \mathrm{p}$. 